\title{
Batch Adsorption Studies on the Removal of Lead(II) from Aqueous Solution Using Typha Angustata L.
}

\author{
T. MOHANAPRIYA and P. E. KUMAR* \\ PG and Research Department of Chemistry, \\ Erode Arts and Science College (Autonomous), Erode, Tamilnadu, India \\ mohanapriyachem@gmail.com
}

Received 21 October 2016 / Accepted 7 November 2016

\begin{abstract}
Batch adsorption studies were carried out for the removal of lead using activated carbon $\mathrm{TiO}_{2}$ nanocomposite. Effect of various factors such as $\mathrm{pH}$, adsorbent dose, contact time, initial concentration and temperature were studied. The kinetics and equilibrium data for the adsorption of lead were analysed by Langmuir and Freundlich isotherm of pseudo first and second order. Pseudo second order kinetics provided the best fit for kinetic data.
\end{abstract}

Keywords: Lead(II), Activated carbon- $\mathrm{TiO}_{2}$ Nanocomposite, Adsorption, Kinetics

\section{Introduction}

Lead is one such heavy metal which, if present in water, can cause many problems. In water, lead is released from lead treatment and recovery industries, especially from lead battery manufacturing units. Lead is toxic to living organisms and if released into the environment can both accumulate and enter the food chain. Lead is known to cause mental retardations, reduces heamoglobin production necessary for oxygen transport and it interferes with normal cellular metabolism ${ }^{1}$. Lead has damaging effects on body nervous system. Many researchers have done the research on using agricultural waste in adsorption of lead. The removal of poisonous $\mathrm{Pb}$ (II) from wastewater by different low-cost abundant adsorbents was investigated by Ghani et $a l^{2}{ }^{2}$ Removal of the poisonous lead ions from solutions was possible using as adsorbents the most effective one.

The effect of contact time, initial metal ion concentration and temperature on metal ions removal had been studied. It was found that adsorbent for removal of heavy metals from wastewater and this process is potentially more economical than any other current process technology ${ }^{3}$. Zuorro et al. ${ }^{4}$ studied to provide some information on the adsorption properties of tea waste and evaluated the removal efficiency of lead ions by spent leaves of green and 
black tea. The results from this study indicated that using adsorbent may be an efficient and economical means for removing lead and presumably, other heavy metal ions from aqueous solutions. The ability of converting a waste product, into an economically cheap adsorbents have been investigated for $\mathrm{Pb}(\mathrm{II})$ and $\mathrm{NO}_{3}$ - removal from aqueous solution through adsorption. The results from this study showed that the chemically modified adsorbent has considerable potentials for the removal of nitrate and $\mathrm{Pb}(\mathrm{II})$ ions from aqueous solutions over a wide range of experimental conditions through adsorption ${ }^{5}$.

Many treatment methods ${ }^{6-16}$ have been reported in literature yet adsorption appears to offer the best prospects for overall treatment of wastewater as the process is useful for a broad range of substances and is normally excepted to be reversible so that regeneration of the adsorbent with resultant economy of operation may be possible. In most of the studies activated carbon ${ }^{17-20}$ has been used as adsorbent. Intensive studies have been carried out to develop more effective and inexpensive adsorbents which was comparable to that of activated carbon.

Thus, the search for good alternatives of activated carbon ${ }^{21}$ is still on. Suitable low $\operatorname{cost}^{22}$ alternative adsorbents are either natural material such as wood, peat, coal, lignite, clays, sand, microorganisms, plant etc., or industrial waste by-products such as slug, fly ash, baggasse, red mud etc. These are generally available free of cost or at very low cost as compared to activated carbon. The utilization of industrial wastes as adsorbents ${ }^{23-28}$ meets to a small extent and beneficial for management of waste disposal problem. Lignin, a byproduct from pulp mill, is a material known to exhibit adsorption properties. Therefore, in the present work, adsorption of most toxic lead metal ion on to activated carbon as an adsorbent has been investigated.

\section{Experimental}

Typha Angustata L. flowers were collected from the Perundurai, at Erode (Dt) in Tamilnadu, India. They were cut into small pieces and dried for 25 days. The flowers were dried and burnt the muffle furnace at $450-500{ }^{\circ} \mathrm{C}$ and kept it for half an hour. The collected the carbonized material was ground well and sieved to a suitable particles size. Activated carbon (AC) has been stored in plastic vessels for the further studies. The particle size of 0.15 to $0.25 \mathrm{~mm}$ was used.

\section{Preparation of $\mathrm{AC}$ - $\mathrm{TiO}_{2}$-Nanocomposite}

Activated carbon $(3 \mathrm{~g})$ was allowed to swell in $15 \mathrm{~mL}$ of water-free alcohol and stirred for $2 \mathrm{~h}$ at $25{ }^{\circ} \mathrm{C}$ to get a uniform suspension. At the same time, the titanium dioxide $(3 \mathrm{~g})$ was dispersed into water-free alcohol $15 \mathrm{~mL}$ then the diluted titanium dioxide was slowly added by dropping it into the suspension of AC and stirring continued for another $5 \mathrm{~h}$ at $25^{\circ} \mathrm{C}$. Then $5 \mathrm{~mL}$ alcohol mixed with $0.2 \mathrm{~mL}$ deionized water was added slowly and stirring continued for another $5 \mathrm{~h}$ at $25^{\circ} \mathrm{C}$. The suspension was then kept overnight for $10 \mathrm{~h}$ at room temperature and the precipitate obtained was carefully dehydrated in a vacuum oven for $6 \mathrm{~h}$ at $80{ }^{\circ} \mathrm{C}$ to a characteristic of the $\mathrm{AC}$ - $\mathrm{TiO}_{2}$-nanocomposite were determined.

\section{Adsorbate solution}

A stock solution of $\mathrm{Pb}^{2+}$ was prepared by dissolving $1.5990 \mathrm{~g}$ of anhydrous $\mathrm{PbNO}_{2}$ in water, acidified with $1 \mathrm{~mL}$ of con.nitric acid and $1 \mathrm{~L}$ of lead solution. Working standards were prepared by diluting different volumes of the stock solution to obtain the concentration. Lead ions concentrations were determined at characteristic wave length $\left(\lambda_{\max }=520 \mathrm{~nm}\right)$ with a double beam UV- Visible spectrophotometer. 


\section{Characterization of absorbent}

Physicochemical characteristics of the adsorbents were studied as per the standard testing methods. The XRD pattern of pure activated carbon and that of $\mathrm{AC}-\mathrm{TiO}_{2}$ nano composition.

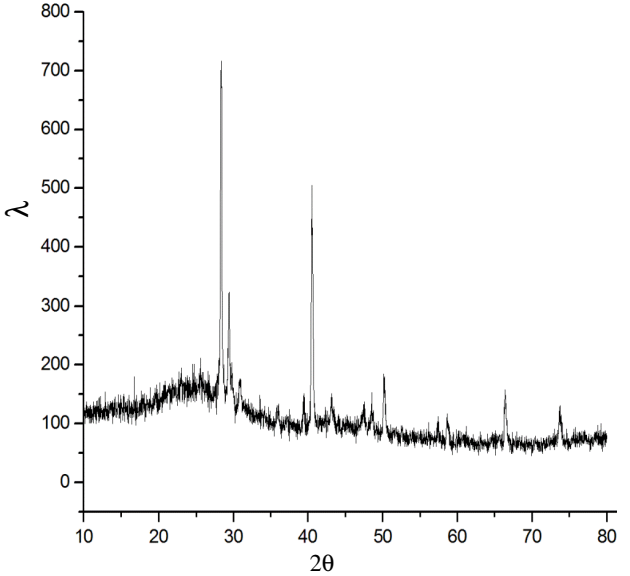

Figure 1(a). X-Ray Diffraction pattern of the activated carbon

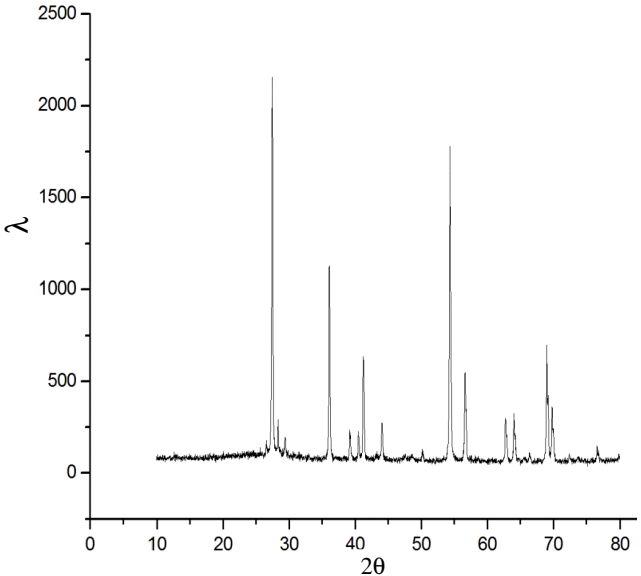

Figure 1(b). X-Ray Diffraction pattern of the activated carbon $-\mathrm{TiO}_{2}$ Nanocomposite

Figure $1(\mathrm{a} \& \mathrm{~b})$ shows characteristics peak at $28^{\circ}$ and $30^{\circ}$, which confirm the presence of $\mathrm{A}-\mathrm{C}-\mathrm{TiO}_{2}$ phase in the nano composite. The recorded patterns were analyzed using to determining peak position, width and intensity. Full-width at half-maxima (FwHm) data was analyzed by Scherer's formula to determine average particle size $t=\frac{0.9 \lambda}{\beta \cos e}$.

The surface morphology of the adsorbent was visualized by scanning electron microscopy (SEM) shown in Figure 2(a \& b). The diameter of the composite range is $10 \mu \mathrm{m}$ to $1 \mu \mathrm{m}$.

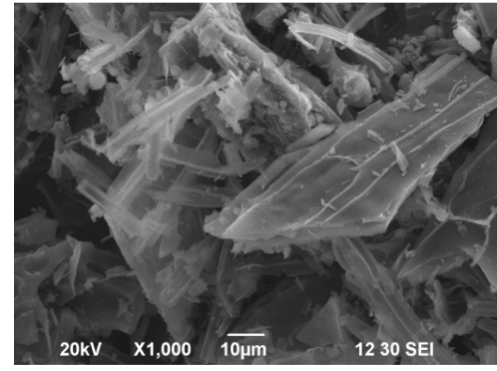

Figure 2(a). SEM image of activated carbon

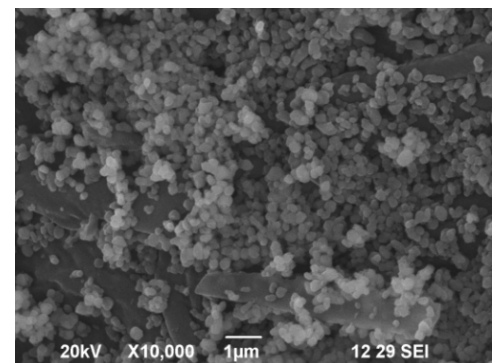

Figure 2(b). SEM image of activated carbon- $\mathrm{TiO}_{2}$ Nanocomposite

\section{FT IR spectroscopy}

The absorption bands are due to the stretching and bending vibration of the group. The frequency of carbon peak is $3425.58 \mathrm{~cm}^{-1}$ and type of band N-H similarly $617.22 \mathrm{~cm}^{-1}$ and type of band $\mathrm{C}-\mathrm{H}$ the frequency of $\mathrm{TiO}_{2}$ peak $655.80 \mathrm{~cm}^{-1}$ is present in $\mathrm{C}-\mathrm{H}$ bonding.

\section{Batch absorption experiment}

Batch adsorption experiments were also performed by agitation $0.1 \mathrm{~g}$ of the adsorbent with $50 \mathrm{~mL}$ of lead solution the $\mathrm{pH}$ containing different initial concentration form 10 to $40 \mathrm{mg} / \mathrm{L}$ 
at $30{ }^{\circ} \mathrm{C}$. After the established contact time (2h) was attained, the suspension was filtered and supernatant was analyzed for the metal concentration of 10 to $40 \mathrm{mg} / \mathrm{L}$ and the adsorbent dosage of $0.1 \mathrm{~g}$ was adjusted in the range of $4-11$ by using dil $\mathrm{HCl}$ and $\mathrm{NaOH}$ solution. Experiments were carried out by varying the adsorbent amount from 0.1 to $1.0 \mathrm{~g}$ with $\mathrm{Pb}(1 \mathrm{ll})$ concentration ranging from 10 to $40 \mathrm{mg} / \mathrm{L}$. The concentration of $\mathrm{Pb}(1 \mathrm{ll})$ in the effluent was determined spectrophotometer by developing a rose colour using $0.01 \%$ PAR reagent, buffer solution as complexing agent in acidic solution.

由 SHIMADZU

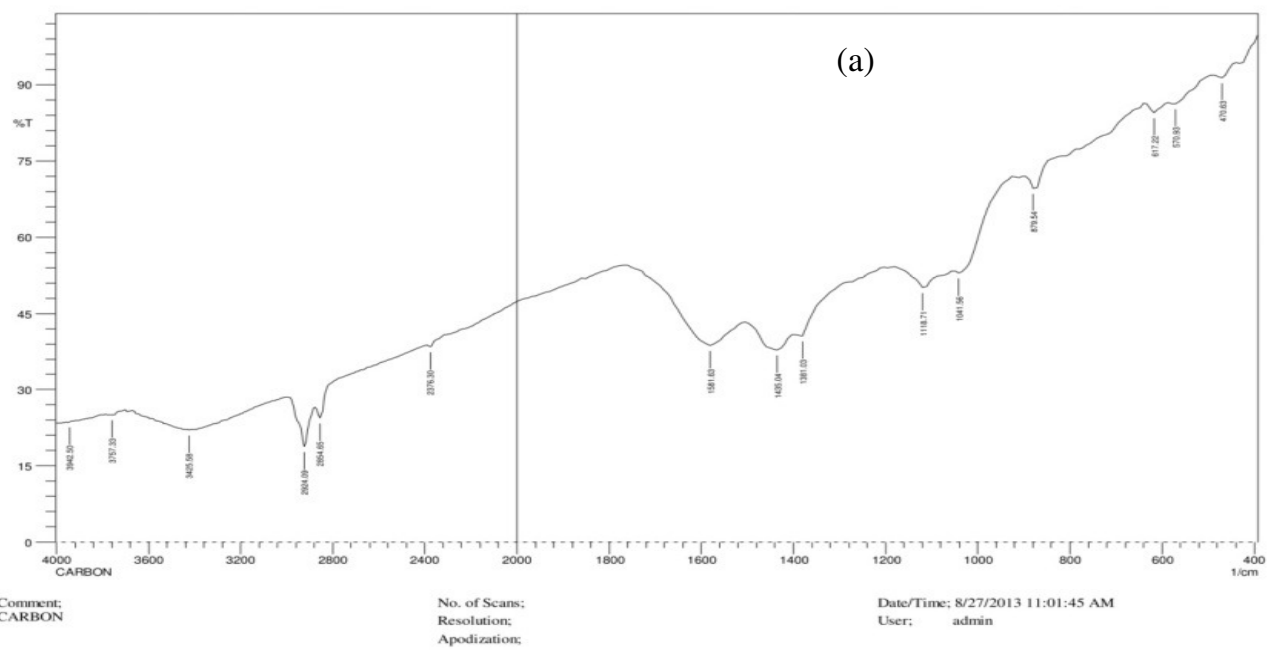

ФSHIMADZU

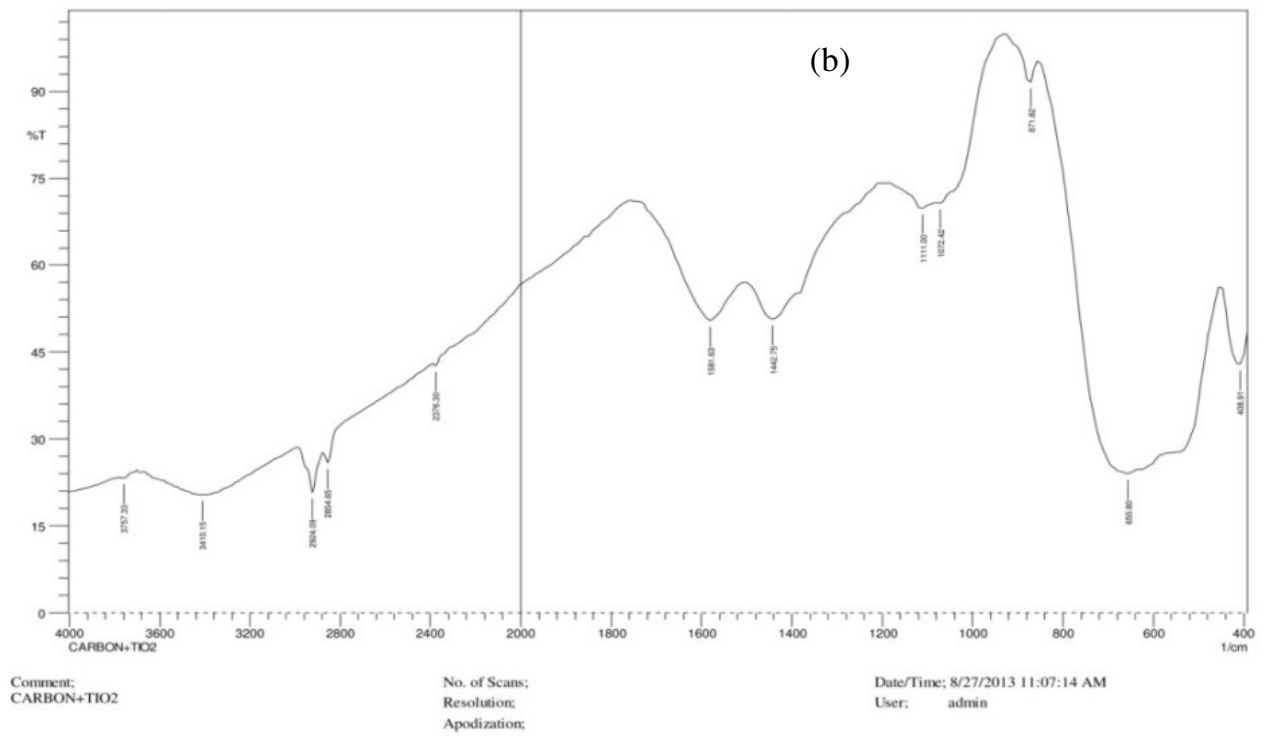

Figure 3. (a) FT-IR Spectrum of activated carbon and (b) FT-IR Spectrum of activated carbon $+\mathrm{TiO}_{2}$ Nanocomposite 
The percentage removal of metal and amount of metal adsorbed on $\mathrm{AC}-\mathrm{TiO}_{2}-$ Nanocomposite was calculated by equation (1) and (2) respectively.

$$
\begin{gathered}
\% \text { Removal }=\frac{100\left(C_{o}-C_{e}\right)}{C_{e}} \\
q_{e}=\frac{\left[C_{o}-C_{e}\right] v}{w}
\end{gathered}
$$

Where $\mathrm{q}_{\mathrm{e}}$ is the quantity of metal adsorbed on the adsorbent at the time of equilibrium $(\mathrm{mg} / \mathrm{L}), \mathrm{C}_{0}$ and $\mathrm{C}_{\mathrm{e}}$ are the initial and equilibrium concentration $(\mathrm{mg} / \mathrm{L}) . \mathrm{V}$ is the volume of solution, $\mathrm{W}$ is the weight of adsorbent.

\section{Adsorption isotherm}

The adsorption isotherm was analyzed using Langmuir, Freundlich and Tempkin isotherm.

\section{Langmuir adsorption isotherm}

The theoretical Langmuir isotherm is often used to describe adsorption of a solute from a liquid solution as

$$
\frac{C_{e}}{q_{e}}=\frac{1}{Q_{0} K_{L}}+\frac{C_{e}}{Q_{0}}
$$

Where $\mathrm{q}_{\mathrm{e}}$ is the amount of metal adsorbed per unit mass of adsorbent $(\mathrm{mg} / \mathrm{L})$ and $\mathrm{C}_{\mathrm{e}}$ is the equilibrium concentration of the adsorbate $(\mathrm{mg} / \mathrm{L})$ and $\mathrm{q}_{0}$ and ' $\mathrm{b}$ ' is Langmuir constants related to adsorption capacity and rate of adsorption respectively. As required by equation 3 , plotting $\mathrm{C}_{\mathrm{e}} / \mathrm{q}_{\mathrm{e}}$ against $\mathrm{C}_{\mathrm{e}}$ gave a straight line, indicating that the adsorption of heavy metal on the nanocomposite follow the Langmuir adsorption isotherm (Figure 4). The Langmuir constant ' $\mathrm{K}_{\mathrm{L}}$ ' is evaluated from the slope and intercept of the graph.

The essential features of Langmuir isotherm can be expressed in terms of a dimensionless constant separation factor $\mathrm{R}_{\mathrm{L}}$ which is defined by the following equation

$$
R_{L}=\frac{1}{1+K_{L} C_{0}}
$$

Where, ' $\mathrm{C}_{0}$ ' is the initial concentration of adsorbate $(\mathrm{mg} / \mathrm{L})$. ' $\mathrm{K}_{\mathrm{L}}$ ' is the Langmuir adsorption constant $(\mathrm{L} / \mathrm{mg})$. $\mathrm{R}_{\mathrm{L}}$ value lies between 0 and 1 indicates favorable adsorption ${ }^{28}$.

\section{Freundlich iotherm}

The Freundlich isotherm ${ }^{27}$ is generally used for mathematical description of adsorption in aqueous system and describes heterogeneous surface energies. The equation can be expressed in logarithmic form as

$$
\log q_{e}=\log k_{f}+1 / n \log C_{e}
$$

Where $\mathrm{q}_{\mathrm{e}}$ is the amount of metal adsorbed in $\mathrm{mgL}^{-1}, \mathrm{C}_{\mathrm{e}}$ is the equilibrium concentration $\left(\mathrm{mgL}^{-1}\right), \mathrm{K}_{f}$ and $\mathrm{n}$ were Freundlich constant. $(\mathrm{mg} / \mathrm{g}, \mathrm{L} / \mathrm{mg})$ related to adsorption capacity and adsorption intensity of the sorbent respectively. The plot of $\operatorname{logq}_{\mathrm{e}} v s . \log \mathrm{C}_{\mathrm{e}}$ gave straight lines with good regression coefficient indicating that the adsorption of heavy metal follow the Freundlich isotherm (Figure 5).

\section{Tempkin isotherm}

Tempkin isotherm is represented by the following equation

$$
q_{e}=\frac{R T}{b} \ln \left[A C_{e}\right]
$$

Equation 6 can be expressed in its linear form as $q_{e}=B \ln A+B \ln C_{e}$ 
Where $\mathrm{B}$ is a constant related to the heat of adsorption $(\mathrm{J} / \mathrm{mol})$ and $\mathrm{A}$ is the Tempkin isotherm constant, corresponding to the maximum binding energy $(\mathrm{L} / \mathrm{mg})$. A plot of qe $v s$. InCe is shown in Figure 6. The values of A and B calculated from the slope and intercept of the graph are given in Table 1.

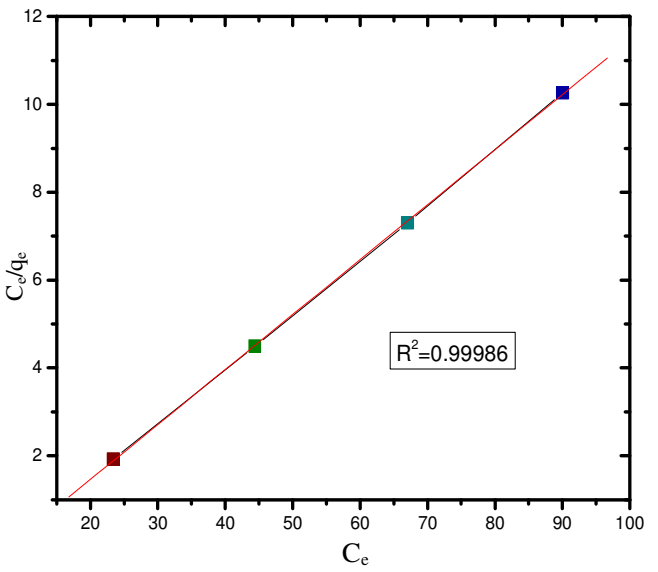

Figure 4. Langumuir plot for the adsorption isotherm

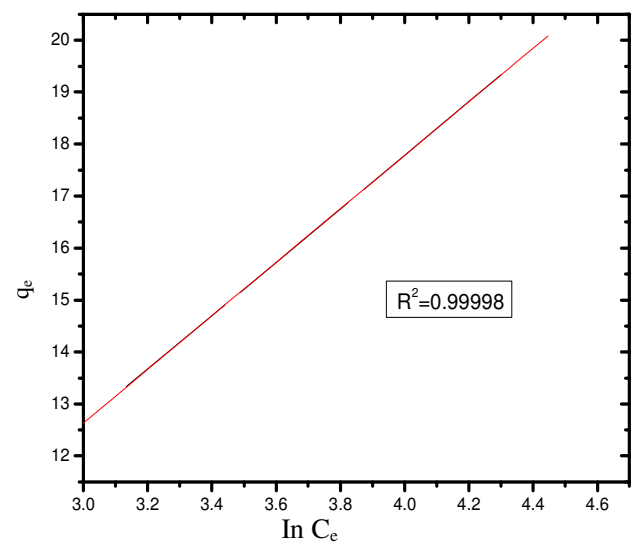

Figure 6. Tempkin plot for the adsorption isotherm

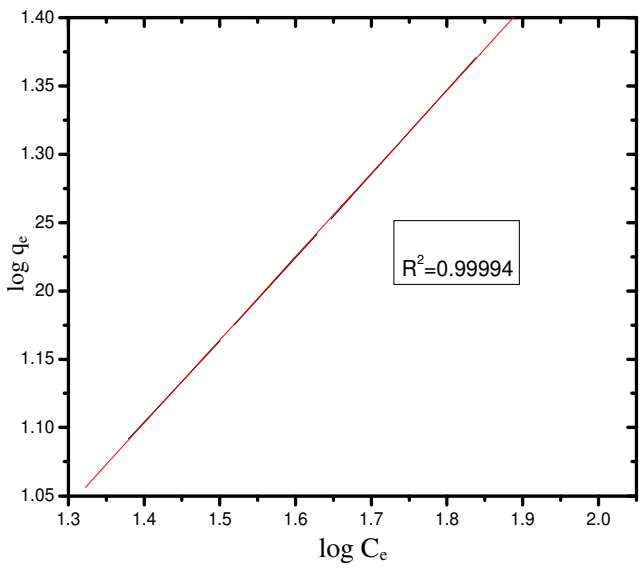

Figure 5. Freundlich plot for the adsorption isotherm

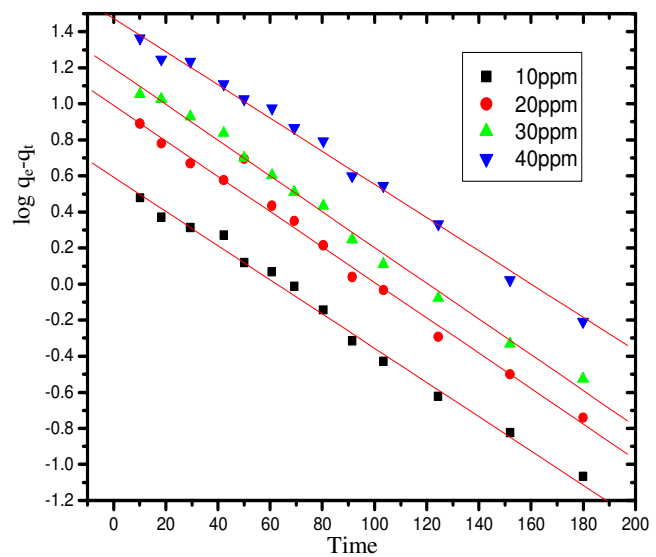

Figure 7. plot of the pseudo first order kinetic model by $\mathrm{AC}-\mathrm{TiO}_{2}-\mathrm{Nanocomposite}$

Table 1. Results of isotherm plots for the adsorption of lead on $\mathrm{AC}-\mathrm{TiO}_{2} \mathrm{AC}$

\begin{tabular}{cccccccccccc}
\hline $\begin{array}{c}\text { Initial metal } \\
\text { concentration, } \\
\mathrm{mg} / \mathrm{L}\end{array}$ & \multicolumn{3}{c}{ Langmuir isotherm } & \multicolumn{3}{c}{$\begin{array}{c}\text { Freundlich } \\
\text { isotherm }\end{array}$} & \multicolumn{3}{c}{ Tempkin isotherm } \\
\cline { 2 - 11 } & $\begin{array}{c}\mathrm{Q}_{0}, \\
\mathrm{mg} / \mathrm{g}\end{array}$ & $\mathrm{b} / \mathrm{mg}$ & $\mathrm{R}^{2}$ & $\mathrm{R}_{\mathrm{L}}$ & $\mathrm{K}_{\mathrm{f}}$ & $\mathrm{N}$ & $\mathrm{R}^{2}$ & $\mathrm{~A}$ & $\mathrm{~B}$ & $\mathrm{R}^{2}$ \\
\hline 10 & & & & 0.2379 & & & & & & \\
20 & & & & 0.1897 & & & & & \\
30 & 7.98 & 0.053 & 0.9998 & 0.1577 & 1.78 & 1.64 & 0.9999 & 0.5821 & 5.139 & 0.9999 \\
40 & & & & 0.1350 & & & & & & \\
\hline
\end{tabular}




\section{Adsorption kinetics}

The kinetics of adsorption of lead by the nano composite and the kinetic models of pseudo first order, pseudo second order and intrapartide diffusion model were considered.

\section{Pseudo first order kinetics}

The pseudo first order kinetics model can be represented as

$$
\log \left(\mathrm{q}_{\mathrm{e}}-\mathrm{q}_{\mathrm{t}}\right)=\log \mathrm{q}_{\mathrm{e}}-\left(\mathrm{k}_{1} / 2.303\right)
$$

Where $\mathrm{q}_{\mathrm{e}}$ is the amount of metal adsorbed at equilibrium $(\mathrm{g} / \mathrm{mg}) . \mathrm{q}_{\mathrm{t}}$ is the amount of metal adsorbed at time $(\mathrm{mg} / \mathrm{g})$ and $\mathrm{k}_{1}$ is the pseudo first order rate constant $\mathrm{k}_{1}$ and $\mathrm{q}_{\mathrm{e}}$ can be calculated from the slope and intercept of the graph (Figure 7). The $\mathrm{q}_{\mathrm{e}}(\mathrm{cal})$ and $\mathrm{q}_{\mathrm{e}}(\mathrm{exp})$ value are shown in Table 2. The adsorption process does not follow first order kinetics.

\section{Pseudo-second order kinetic model}

The linear pseudo second order kinetic equation is given as.

$$
\mathrm{t} / \mathrm{q}_{\mathrm{t}}=1 /\left(\mathrm{k}_{2} \mathrm{q}_{\mathrm{e}}^{2}\right)+1 / \mathrm{q}_{\mathrm{e}} \mathrm{t}
$$

Where $\mathrm{k}_{2}$ is rate constant of second order adsorption $\left(\mathrm{g} \mathrm{mg}^{-1} \mathrm{~min}^{-1}\right)$. As expected the plot of $\mathrm{t} / \mathrm{q}_{\mathrm{t}} v s$. $\mathrm{t}$ (Figure 8) was linear. The values of $\mathrm{q}_{\mathrm{e}}$ and $\mathrm{k}_{2}$ can be calculated from the slope and intercept. The $\mathrm{q}_{\mathrm{e}}(\mathrm{cal})$ and $\mathrm{q}_{\mathrm{e}}(\mathrm{exp})$ values are shown in Table 2 . The calculated $\mathrm{q}_{\mathrm{e}}(\mathrm{cal})$ values are in consonance with $\mathrm{q}_{\mathrm{e}}(\mathrm{exp})$ with high correlation coefficient values. The adsorption of $\mathrm{AC}^{-\mathrm{TiO}_{2}}$-Nanocomposite followed pseudo-second order kinetics.

\begin{tabular}{|c|c|c|c|c|c|c|c|c|c|c|c|}
\hline \multirow{2}{*}{$\begin{array}{c}\text { Initial } \\
\text { metal } \\
\text { concen } \\
\text { tration, } \\
\mathrm{mg} / \mathrm{L}\end{array}$} & \multicolumn{4}{|c|}{ Pseudo first order } & \multicolumn{4}{|c|}{ Pseudo second order } & \multicolumn{3}{|c|}{ Intraparticle diffusion } \\
\hline & $\mathrm{k}_{1}$ & $\mathrm{q}_{\mathrm{e}}(\exp )$ & $\mathrm{q}_{\mathrm{e}}(\mathrm{cal})$ & $\mathrm{R}^{2}$ & $\mathrm{k}_{2}$ & $\mathrm{q}_{\mathrm{e}}(\exp )$ & $\mathrm{q}_{\mathrm{e}}(\mathrm{cal})$ & $\mathrm{R}^{2}$ & $\mathrm{~K}_{\mathrm{id}}$ & $\mathrm{C}$ & $\mathrm{R}^{2}$ \\
\hline 10 & 0.0218 & 4.668 & 3.9139 & 0.9855 & 0.0052 & 4.668 & 5.5710 & 0.9976 & 0.4454 & 0.2921 & 0.9797 \\
\hline 20 & 0.0225 & 9.537 & 9.7566 & 0.9806 & 0.0008 & 9.537 & 13.952 & 0.9904 & 0.7526 & 0.5816 & 0.9945 \\
\hline 30 & 0.0228 & 14.289 & 15.649 & 0.9943 & 0.0042 & 14.289 & 23.435 & 0.9818 & 1.3272 & 1.1317 & 0.9946 \\
\hline 40 & 0.0211 & 19.219 & 29.689 & 0.9876 & 0.0002 & 19.219 & 32.679 & 0.9845 & 1.5567 & 0.6552 & 0.9972 \\
\hline
\end{tabular}

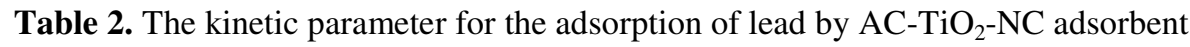

\section{Intraparticle diffusion}

The intraparticle diffusion model used here refers to the theory proposed by Weber and Morris ${ }^{28}$ based an intraparticle diffusion coefficient $\mathrm{K}_{\mathrm{id}}$ is defined by the equation,

$$
\mathrm{q}_{\mathrm{t}}=\mathrm{k}_{\mathrm{id}} \mathrm{t}^{1 / 2}+\mathrm{C}
$$

Where $K_{\text {id }}$ is the intraparticle diffusion rate constant $\left(\mathrm{mg} / \mathrm{gmin}{ }^{1 / 2}\right), \mathrm{C}$ is the intercept $(\mathrm{mg} / \mathrm{g})$ can be calculated by plotting $\mathrm{q}_{\mathrm{t}} v s$. $\mathrm{t}^{1 / 2}$ and the results are given in Figure 9 and Table 2. The linear portion of the plot does not pass through the origin. Such a deviation from the origin indicates that pore diffusion is the only controlling step and not the film diffusion.

\section{Thermodynamic parameters}

The thermodynamic parameters for the sorption process could be determined from the experimental data obtained at various temperatures using the equation

$$
\begin{gathered}
\ln k_{c}=\Delta S^{o} / R-\Delta H^{o} / R T \\
\Delta G^{o}=\Delta H-T \Delta S
\end{gathered}
$$

Where $\mathrm{k}_{\mathrm{c}}$ is the Langmuir constant related to the energy of adsorption, $\mathrm{R}$ is the gas constant and $T$ is the absolute temperature $(\mathrm{K})$. The adsorption process such as free energy change $\left(\Delta \mathrm{G}^{\mathrm{o}}\right)$, enthalpy change $\left(\Delta \mathrm{H}^{\circ}\right)$ and entropy change $\left(\Delta \mathrm{S}^{\circ}\right)$, suggest that endothermic and spontaneous. 


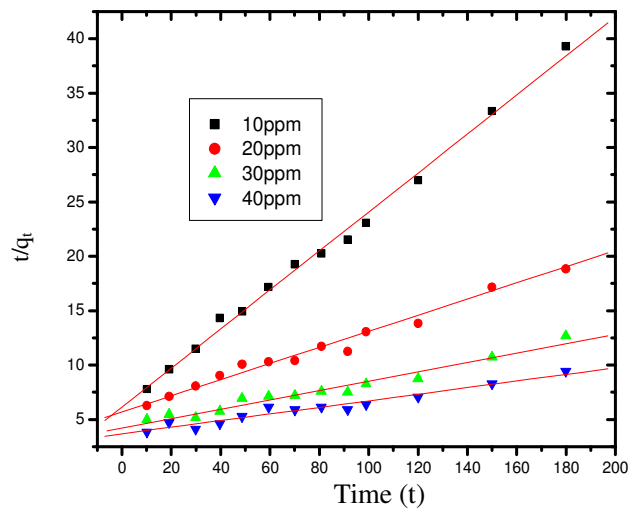

Figure 8. Plot of the pseudo second order kinetic model byAC-TiO 2 -Nanocomposite

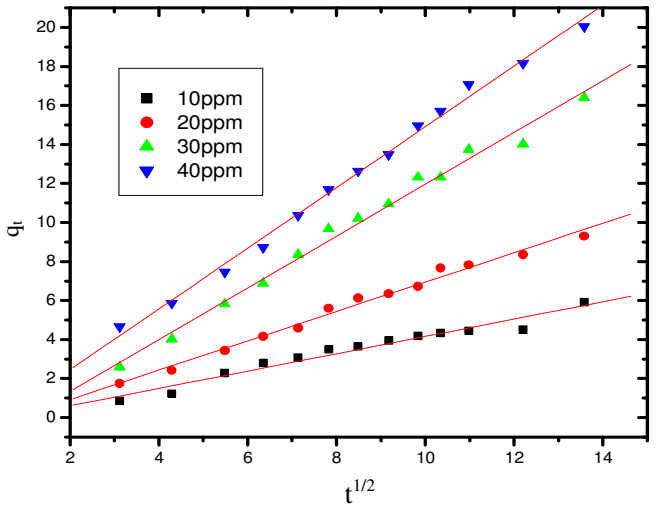

Figure 9. Plot of the intraparticle diffusion kinetic model byAC-TiO ${ }_{2}$-Nanocomposite

\section{Results and Discussion}

\section{Effect of contact time and initial metal concentration}

The effect of contact time shows that equilibrium is achieved faster 10 to $210 \mathrm{~min}$ with nano composite. It is observed that in both cases the percentage removal of $\mathrm{Pb}$ (II) ion increase with increase in metal ion concentration Figure 10. The rate of adsorption is very fast initially with about $96 \%$ of the total lead being removal within few minutes followed by an increased rate with the approach of equilibrium. The removal rate is high initially due to the presence of the binding sited which gradually become saturated with time resulting in increases rate of adsorption as equilibrium approached finally attain.

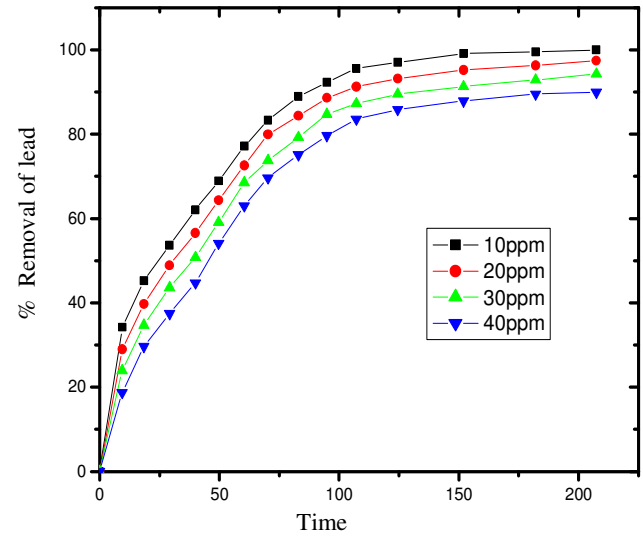

Figure 10. Effect of agitation time and initial metal ion concentration $\mathrm{Pb}$ by $\mathrm{AC}$ $\mathrm{TiO}_{2}$-Nanocomposite

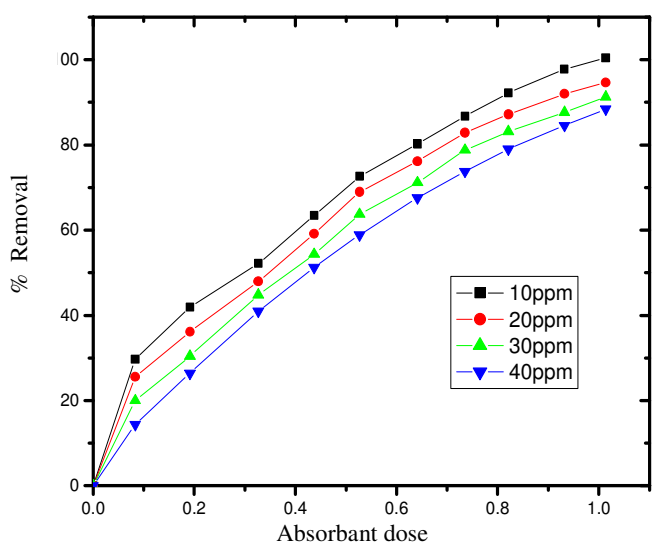

Figure 11. Effect of the adsorbent dosage for $\mathrm{Pb}$ by $\mathrm{AC}-\mathrm{TiO}_{2}-\mathrm{Nanocomposite}$

\section{Effect of adsorbent dosage on adsorption process}

The effect of dose adsorbents under study on the removal of lead is shown in Figure 11. This illustrates the adsorption of lead ion with change of the adsorbent dose from 0.1 to $1.0 \mathrm{~g}$. The results showed that within the amount increase in adsorbent concentration there is an increase adsorbed per unit mass of the adsorbent. 


\section{Effect of temperature}

Temperature studies shown in Figure 12 at different temperatures $30,34,38$ and $40{ }^{\circ} \mathrm{C}$. It is observed that adsorption of lead ions increases with increasing temperature showing the process to be endothermic.

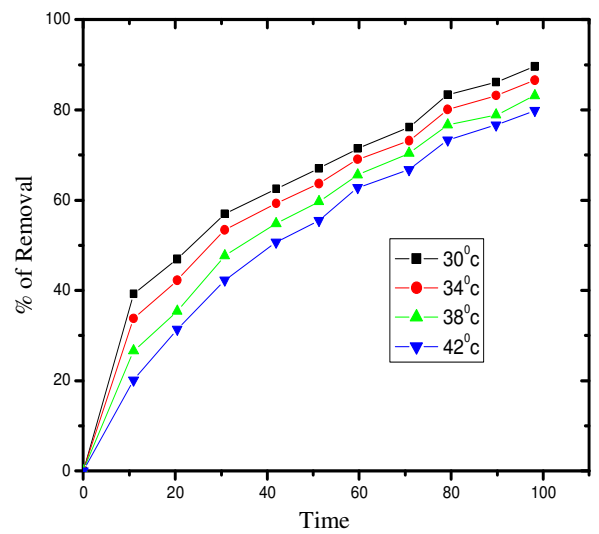

Figure 12. Effect of Temperature for $\mathrm{Pb}$ by $\mathrm{AC}-\mathrm{TiO}_{2}-\mathrm{Nanocomposite}$

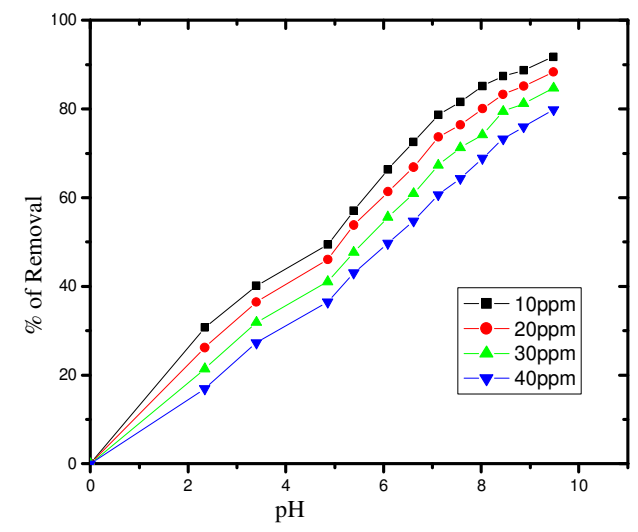

Figure 13. Effect of $\mathrm{pH}$ for $\mathrm{Pb}$ by $\mathrm{AC}-\mathrm{TiO}_{2}-$ Nanocomposite on metal ion

\section{Effect of $p H$}

Adsorption of $\mathrm{Pb}(1 \mathrm{l})$ was studied at various $\mathrm{pH}$ values and results are depicted in Figure 13. The initial $\mathrm{pH}$ of solution was varied from 4 to 10 with the adsorbate various concentration of $10-40 \mathrm{mg} / \mathrm{L}$ maintaining the adsorbent dose at $0.1 \mathrm{~g}$ and the contact time at 2 hours for nanocomposite. The residual $\mathrm{Pb}(\mathrm{II})$ ions were analysed with atomic absorption spectrophotometer. From this figures it is clear that lead adsorption efficiency is highest at $\mathrm{pH} 8-11$ with nanocomption $\mathrm{pH}_{\mathrm{ZPC}}$ for the nanocomposition was determined as 9.0.

\section{Adsorption isotherms}

The capacity of the adsorption isotherm is fundamental and plays an important role in the determination of the maximum capacity of adsorption. In order to adapt for the considered system, an adequate model that can reproduce the experimental results obtained, equations of Langumuir, Freundlich, Tempkin have been considered

\section{Adsorption kinetics}

The study of adsorption kinetics is significant as it provides valuable information about the reaction pathways and the mechanism of the reaction. The kinetics of Pd(II) on activated carbon - $\mathrm{TiO}_{2}$ nanocomposite was analyzed using pseudo first order, pseudo second order, and intra particle diffusion models.

\section{Thermodynamic parameter}

Thermodynamic parameters provide in-depth information of inherent energetic changes associated with adsorption; therefore, these parameters should be accurately evaluated. The thermodynamic values were calculated from the graph plotted between $\operatorname{lnk}_{\mathrm{c}} v s, 1 / \mathrm{T}$ (Figure $14 \&$ Table 3). Changes to $\Delta \mathrm{G}^{\circ}, \Delta \mathrm{H}^{\mathrm{o}}$ and $\Delta \mathrm{S}^{\mathrm{o}}$ were calculated to elucidate the process of adsorption. The low $\Delta \mathrm{H}^{\mathrm{o}}$ value depicts $\mathrm{Pd}$ ion are chemisorption onto adsorbent activated carbon. $\mathrm{TiO}_{2}$ nanocomposite the negative values of $\Delta \mathrm{G}^{\mathrm{o}}$ shows the adsorption is highly favorable and spontaneous. 


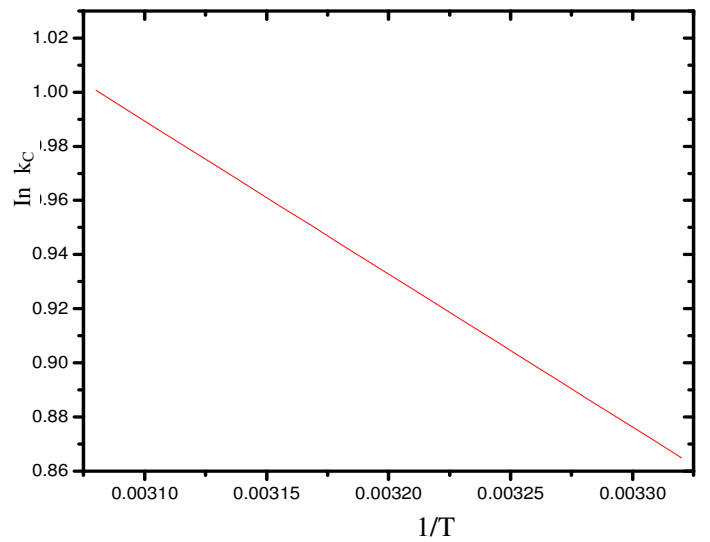

Figure 14. Eyring plot

Table 3. Thermodynamic parameter values

\begin{tabular}{cccccc}
\hline \multicolumn{4}{c}{$\Delta \mathrm{G}^{0}, \mathrm{~kJ} / \mathrm{mol}$} & $\Delta \mathrm{S}^{0}, \mathrm{~J} / \mathrm{mol} / \mathrm{K}$ & $\Delta \mathrm{H}^{0}, \mathrm{~kJ} / \mathrm{mol}$ \\
\hline $303 \mathrm{~K}$ & $307 \mathrm{~K}$ & $311 \mathrm{~K}$ & $314 \mathrm{~K}$ & \multirow{2}{*}{148.516} & 43.612 \\
\hline-42.038 & -43.126 & -45.712 & -48.107 & & \\
\hline
\end{tabular}

\section{Desorption studies}

Desorption studies with acetic acid revealed that the regeneration of adsorbent was not satisfactory, which confirm the chemisorptive nature of adsorption.

\section{Conclusion}

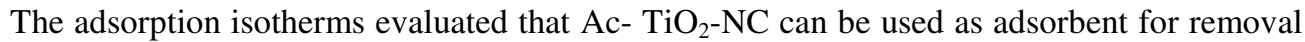
of lead ion. The amount of metal adsorbed varied with initial metal concentration, adsorbent dose, $\mathrm{pH}$ and temperature. Adsorption isotherms of the adsorbents under study were evaluated using Freundlich, Langmuir and Tempkin isotherm. The kinetic results for the experimental data of adsorption the lead onto activated carbon $\mathrm{TiO}_{2}$ nanocomposite were better follows pseudo second order equation. Desorption studies reveals that satisfactory which confirms the chemisorptive nature of adsorption. The sorption process was found to be endothermic and spontaneous.

\section{References}

1. Qaiser S, Saleem A R and Ahmed M M, Environmental Biotechnol., 2007, 10(3), 1-8.

2. Abdel Ghani N T, Hefny M and El-Chaghaby G A, Int J Environ Sci Technol., 2007, 4(1), 67-73; DOI:10.1007/BF03325963

3. Bulut Y and Zeki T, J Environ Sci., 2007, 19(2), 160-166; DOI:10.1016/S10010742(07)60026-6

4. Zuorro A and Lavecchia R, Am J Appl Sci., 2010, 7(2), 153-159;

DOI:10.3844/ajassp.2010.153.159

5. Goncharuk V V, Kucheruk D D, Kochkodan V M and Badkha V P, Desalination, 2002, 143(1), 45-51; DOI:10.1016/S0011-9164(02)00220-5

6. Graham N J D, Brando C C S and Luckham P F, J Am Water Works Asso., 1992, 84, 105-113.

7. $\quad$ Lin S.H. and Peng C F, Water Res., 1996, 30(3), 587-592; DOI:10.1016/00431354(95)00210-3 
8. Mazumdar S, Upadhyay Y D and Upadhyay S N, RAWM, BHU, Varanasi, 2001, 23.

9. Kumar V and Upadhyay S N, Computers Chem Eng., 2000, 23(11-12), 1713-1724; DOI:10.1016/S0098-1354(99)00319-1

10. Kang S, Liao C and Po S, Chemoshpere, 2000, 41(8), 1287-1294; DOI:10.1016/S0045-6535(99)00524-X

11. Tanaka K, Padermphole K and Hisanaga T, Waste Res., 2000, 34, 324.

12. Kumar P E, Studies on Characteristics and Fluoride Removal Capacity of Jambonut Carbon. M.Phil, Disseration: Bharathiar University, Coimbatore, 1991, Tamilnadu, India.

13. Kumar P E and Perumal V, Nature Environment Pollution, 2010, 9(3), 513-518.

14. Ogtuveren U and Kaparal S, J Environ Sef Health, 1994, A29, 1-16.

15. Vasant Kumar K, Ramamurthi V and Sivanesan S, Process Biochem., 2005, 40(8), 2865-2872; DOI:10.1016/j.procbio.2005.01.007

16. Churcley J, Ozone-Science Engineering, 1998, 20, 111-120; DOI: $10.1080 / 01919519808547280$

17. Coia Ahlman S and Groff K A, Res J Water Poll Cont Fed., 1990, 62, 473-478.

18. Mall I D, Pandey P M, Prasad B and Singh Arvind, Chemical Engg World, 2001, 36(12), 156-159.

19. Nakamura T, Tanda S, Kawasaki N, Izawa J and Tokimoto T, Toxicol Environ Chem., 1995, 47, 213-222; DOI:10.1080/02772249509358142

20. Perrich J R, (CRC Press. Inc. USA), Boca Rator, Florida, 1981.

21. Yang Jun and Wang Yunxiu, J Environ Sci., 1994, 6, 173.

22. Stephen Inbaraj B and Sulochona N, Ind J Chem Technol., 2002, 9(3), 201.

23. Mall I D, Dixit S, Singh D, Singh A K and Srivastava V C, IPPTA J., 2005.

24. Namasivayam C and Yamuna R T, Environ Pollut., 1995, 89(1), 1-7; DOI:10.1016/0269-7491(94)00056-J

25. Namasivayam C, Munaiswamy N, Gyatri K, Rani M and Ranganathan K, Biosource Technol., 1996, 57, 37-43; DOI:10.1016/0960-8524(96)00044-2

26. Norrozi B, Sorial G A, Bhrami H and Arami G A, J Hazardous Materials, 2007(B), 139, 167-174.

27. Freundlich H M, J Phys., 1906, 57, 385-470

28. Weber WJ and Morris J C, Am Soc Civ Eng., 1963, 89, 31-39.

29. Vasant Kumar K, Ramamurthi V and Sivanesan S, Ind J Environ Ecoplanning, 2004, 8(1), 59-62. 